Claremont Colleges

Scholarship@ Claremont

CMC Faculty Publications and Research

CMC Faculty Scholarship

$1-1-2007$

\title{
The Scholar and Her Servants: Further Thoughts on Postcolonialism and Education
}

Nita Kumar

Claremont McKenna College

\section{Recommended Citation}

Kumar, Nita. "The Scholar and Her Servants: Further Thoughts on Postcolonialism and Education." The Politics of Gender, Community and Modernities: Essays on Education in India. New Delhi: Oxford University Press, 2007.

This Book Chapter is brought to you for free and open access by the CMC Faculty Scholarship at Scholarship @ Claremont. It has been accepted for inclusion in CMC Faculty Publications and Research by an authorized administrator of Scholarship @ Claremont. For more information, please contact scholarship@cuc.claremont.edu. 


\section{Chapter 12}

\section{The Scholar and her Servants: further thoughts on Postcolonialism and Education}

The hypothesis of the paper is twofold. By juxtaposing the two subject-positions of mistress and servant, moving between one and the other to highlight how each is largely constructed by the interaction, we illuminate the questions of margin and centre, silence and voice, and can ponder on how to do anthropology better. But secondly, to the work of several scholars who propose various approaches to these questions, I add the particular insight offered by the perspective of education. Because one of the subject-positions is that of 'the scholar', someone professionally engaged in knowledge production, the new question I want to consider is regarding the formation of this authoritative knowledge, its seemingly autonomous history, and the existing and potential intersections of that history with the history of the 'non-scholar'. If I study India the question is how the history of India impinges on the history of the subjects involved in the study. The solution proposed is a radical one. Might one consider that the fancily educated, laboriously trained western or modern indigenous scholar who is in the field to do her research for degree or publication may contribute something to the necessary education of her less-thanperfectly educated informants? If this sounds illegitimate or unfeasible, I suggest that it is so because of certain problems in our understanding of 'colonialism' and 'culture', and that these could be resolved particularly by reflecting further on several histories. My suggestion then is to work to create what I call a postcolonial context, defined by the attempt to minimize the dichotomy between the scholar as subject and her non-scholarly, indeed, unschooled, subjects of study.

\section{The Scholar learns, and the Informant---knows?}

The relationship of the scholar and her informant, each, to education, has multiple dimensions. As my heading above announces, however, the basic division between the two is reflected in the fact that the scholar is the dynamic being, and the informant the static one. This is not only in terms of the obvious mobility of the scholar travelling to the research site and making contact and uncovering data, while the informant is already settled there and travels nowhere. It is in terms of the dynamic quality of learning versus the static quality of 'knowing'. Apart from busily acquiring knowledge through school, college, and university, the scholar is educated in 
the field, through her fieldwork, which serves to complete a degree, advance a career, or simply project her as now (even) more knowledgeable. It used to be not explicit as to what role the people in the field play in this education.

More recently, not only does the discipline problematize the position of the researcher vis-àvis the research [(Asad 1973, Borofsky 1997, Clifford and Marcus 1986, Marcus and Fischer 1986, Obeyesekere 1992, Rosaldo 1989)] many anthropologists specifically acknowledge the education they have received from their informants in new, human, terms. Unstated in most cases is that the informants in question were far less 'educated' than the scholars, and this in at least two ways. One, that the informants were formally less educated, that is, they were less schooled. Not only is every scholar in this situation either a candidate for, or actually possesses, one of the highest degrees, a Doctor of Philosophy, she has typically acquired it or its candidacy in a modern institution (western or based on western premises) with rigorous standards of examination and graduation. Two, she is also typically a member of the intelligentsia and in the view of an anthropologist of the west like myself, to be clearly distinguished from the general public in her society. Such a member of the Western intelligentsia has many characteristics, among them broad-mindedness and belief in cultural relativism. She goes beyond, or strives to, the trappings of her modernity. This difference between the western intellectual and the average western citizen is hardly noted, whereas the parallel difference between the modern, say, Indian intellectual, who is secular, democratic, progressive unlike most of her fellow citizens (it is claimed), is unfailingly mentioned by scholars (see Van der Veer 1994, specially pp 159-60, 16364). The bulk of the population in societies like the USA's are ill-informed and prejudiced about other societies and cultures. Higher education and research serves to de-nationalize the scholar to the extent of being publicly and professionally (not necessarily personally) open to alternative values and lifestyles. Without being necessarily personally interested in the practices of her informants (indeed she typically is not), the Western scholar does view these 'foreign' practices with neutrality and professional interest which translates in the scholar-subject relationship into respect for the informant and a lack of ethnocentricity. Thus the scholar is better educated twice over: formally, in schools; and ethically, in a humanistic, scholarly tradition that would not accept hierarchising other cultures as lower than one's own. The informant is worse educated because even if formally schooled, the school is likely to be an average or poor one, or, if excellent, in an indigenous, alternative-to-modernity mode (of shamans, pandits, midwives). And the informant is likely to seem ethnocentric and narrow-minded about her beliefs, without the desire or capacity to put them in a universal, comparative perspective. I say 'seem' rather than 'is', because poor and informally educated people in countries like India can, and do, have amazing tolerance for those 
with unheard of backgrounds and habits. This, important as it is, is not a structural characteristic, as I argue in this paper; it does not empower them in structural ways as it does a declassed Western or indigenous intellectual.

Many anthropologists acknowledge the subtler education they receive from their informants. At the simplest level, this may be a case of mastering a language, or translating a text or discourse (Trawick 1990:14-40). At a more abstract level, it would be learning discourse in the wider sense, as epitomized in the image of the anthropologist enacting the role of a child in order to learn a culture from the inside. A more personal version of the same is the scholar admiring the etiquette, poise, and interactional finesse of one or more informants and comparing them unfavourably to his/her own bumbling and tension (Gold 1988: preface; Geertz 1973; Kumar 1992).

I am not aware of discussions that link the paradigm of Orientalism with this particular experience or choice of scholar-subject relationship in the field, but it seems like an obvious link to make. The native of Bali, or Ghatiyali, or Tamilnad, is supposed to be simply 'different', more rarefied, less temperamental a being, to 'know' something, which the scholar then tries to 'learn'. Gold is more subtle in her suggestions that it was her own particular background and personality that created the confusions that initially arose for her in the field, and both Gold and Raheja then successfully incorporate their fieldwork experiences in a search for the particular subject-positions of their informants (Raheja and Gold 1994: Preface). Geertz's othering is certainly benign as compared to that of those implicated in colonial forms of Orientalism, but it is no less obfuscating about the self-reflexive nature, will, and agency of the native. What is definitely missing from his account is the possible wish of the informant to also learn, or what I would like to call "the will to education" of the informant.

Yet another kind of education occurs particularly for women ethnographers in the sense of learning from "the strong, self-possessed Indian women who have been our teachers" (Gold 1992: 27) even when the scholar acknowledges herself to be less than sweet, obliging and eventempered, that is, a strong woman herself (Trawick 1990: 5). Finally there is the more recent case of developing new ethnographic strategies as by Abu-Lughod (1993) who patiently allows women's own narratives their voice without injecting comments, analytical or judgemental. Again, the women with the narratives are wiser. What I continue to find problematic is the implication that these women informants "know". They have wisdom. It would seem that they will not perceive something new in what they encounter, as the scholar has just done; that they do not also learn and change, as the scholar does; that they have no will to education, as the scholar does. 


\section{The Subjects of this Study}

In this essay, I am talking, on the one hand, about the anthropologist as an informant, a professional teacher of, say, twenty to thirty years' standing, possessed of the ambition to know and learn endlessly, and broadcast this knowledge to the world. This Subject, here, I, includes within it its history: those responsible for its formation, in this case two main groups of people and their knowledge systems: her teachers, mostly men or normatively male women, the ones who literally taught and guided her, and the innumerable (male) writers she learnt from in quieter ways; and her 'teachers', the mother figures who have filled in her epistemologies and cosmologies, literally innumerable aunts, great aunts, other relatives, friends, and voices all around.

Her Subjects, on the other hand, are her servants as informants, the products of certain systems, materials and cultural, of production, in a North Indian small town. There is a clear overlap between the two Subjects. Although poor, the informants are from the same pool as the mother-figures. Mothers and aunts are typically not professional scholars and, even if upper class, share the 'cultural world' of women of classes lower than theirs. Then, the scholar-subject might be actually taught by servants as she is growing up, or by others in her environment who form her common sense and epistemology in numerous intangible ways.

My argument is a precise one for the indigenous scholar, part of a possible larger argument regarding the formation of an indigenous intellectual class, from among whom would come all the Indian scholars who work on India. Recent discussion of the positioning of the indigenous scholar does not specifically discuss her history as class formation, and the implications of this, for instance, in India, of class as related to education. As I discuss below, it is crucial to incorporate the history in any possible strategy of purposefully negotiating that history, of fashioning a postcolonial politics to overcome the rampant colonialism of the present.

The case of Western scholars abroad is a more complicated one that I can only broach here, but is totally related. There are several ways to open up this discussion. One could argue that “We [the west] have never really been Modern” (LaTour 1993): that so-called Modernity consists of 'hybrids' and not pure forms, of rationality, science, and so on. One could argue in a historical vein to show that the western scholar is also taught and socialized in ways and by people who bear a strong resemblance to those who will be her informants when she is a professional adult. More structurally, one could argue that if one sees the world as a whole, the very identity of the Western scholar presupposes the identities of those who are her Others and that she is constructed in every possible way by the historical trajectories that have produced what 
seem like different worlds but which all flow into and form each other, not least through colonialism. ${ }^{\mathrm{i}}$

Although my immediate arguments concern an indigenous scholar working in her own society, and these above approaches can only be opened up in this paper, one of the most obvious overlaps between even the western scholar and her poor, Third World village informants that suggests itself is that of gender. When the scholar is a woman and is studying women, it seems difficult to imagine that she can remain indifferent to this commonality of gender even as other very stark differences, of civilization, culture, development level, and education between her and her informants yawn constantly in front of her in her research. Then, as the commonality of gender presents obstacles, it should become apparent that more central to the relationship still is class. But in the case of the 'international' research relationship, class difference becomes fallaciously translated as national difference, but is in any case not discussed as class ${ }^{\mathrm{ii}}$.

With that, I turn to the specific Subjects of this discussion, the scholar/informant and her servants/informants. The problems I present here arose from some one decade of my own work with poor women in North India in which I was trying to discover their experiences of work, leisure, and everyday life. I encountered an obstruction in the practice of what I was used to respecting as the ethnographic method, that of attending carefully to the informants' representations and taking it seriously as my data. The problem I had was the following:

First, the question of gender consciousness, as reflected in personal biography. What when the thought processes of the informants are patently lacking in some awareness that occurred to the scholar herself in her own quite recent memory? My mother-figures too tried to teach me of the virtues of self-sacrifice with illustration from the cases of Sati and Savitri, the North Indian Hindu models of domesticity and husband-worship. I could plot quite reflexively and ironically the course I followed in my development in shaking off of the repressive dimensions of such teachings to realize that I could be good and normal without buying into this discourse of selfsacrifice. So, when my informant tells me seriously that what is special about Indian women is that they are all potential, struggling Satis and Savitris, I see in her the woman not yet questioning and reflexive. I see her as susceptible to new awareness and change, and not least because of experience with precisely such processes of gender awareness on the part of myself and others in recent years.. If she is younger than me, I have no hesitation in ascribing her restricted beliefs to age and that takes the burden off my shoulders. But if she of my age, or senior, or more typically age unknown but senior enough, I face the dilemma: should I orientalize her, by constructing her as simply 'different', as 'naturally' tied to certain ideas? Should I be distanced in my cultural relativism and pretend that whatever she says is harmless? Should I take on my feminist politics 
and treat her as an involuntary member of the women-of-the-world circle whose consciousness must be raised? Or should I try something new: treat her as an equal to me where as two equals we subscribe to two different discourses and in respect to her, I must share mine with her as she is sharing, innocently, hers with me? Her discourse could be less than innocent too, in cases where the informant is self-righteous or merely chock-full of her seniority, and implicitly or explicitly condemns me and my (imagined) principles and seeks to educate and dominate me in/with something better.

Second, the question of History, with a capital $\mathrm{H}$, as in the History of the nation state with its processes of education and class formation. The History of India has been characterised by the separation of classes on the basis of their access to colonial English-medium education, together with its disciplines such as Western sciences, philosophies and histories. The elite are those who have this access, and the underclass and provincialized are those, educated as they may be in other knowledge formations, do not have this access. An informant who voices certain ideas re:, for instance, menstruation, is a good case in point. I am aware that ideas about menstruation are part of the cultural systems that anthropologists regularly study, and that 'scientific' ideas themselves are not gender-free or culturally neutral. I am aware of the generations of missionary women who have come to South Asia and felt upset by the distorted limbs, weakened bodies and unsuccessful childbirths that resulted from ignorance about the female body. The lines of such noble professional colleagues and ignoble colonial foremothers should effectively silence one against speaking out against an informant's cultural beliefs. My argument is that this informant is not different in culture from the scholar, but the product of the same history of class formation that has produced her and the scholar as certain kinds of knowledge products. To show her a drawing of a woman's bodily systems and explain how certain processes occur and are not morally marked is also a potential part of her history and therefore her culture. When she is aware of many possible explanations, as supposedly the scholar is, she could still choose to discard some and retain others. But at the moment, as a result specifically of the history of the state she belongs to, she is ignorant.

But, third, there is the very possibility of becoming de-classed through an understanding of History and class. What when the scholar becomes aware of no fear of 'culture' any more? Partly because of the questioning of the culture concept that is so familiar to us by now, and partly from my reflections on my own placing vis-a-vis my informants, through prolonged work with them, I for one am comfortable with a profound scepticism of the 'real' and the 'authentic'. The 'real' (body, culture) is as much mine as theirs. The culture has, and has always had, room for difference and variation, ranking and self-questioning. For every woman who says, "A female 
body is a fragile clay pot", another woman can, and does, say, "A woman's body is her own for her to define." Nothing I say or do makes me feel inauthentic, 'un-Indian', or out of touch with people from my society.

The discomfort now is greater. Not because I am so different and distanced from the 'people' I study and blame myself for it, but because I am aware of gender, History, and class, that together make me complicit with a structural violence at the heart of the scholar-informant relationship that I no longer wish to be inept at dealing with.

One source for my present comfort/discomfort in my questioning is that I have had some twenty maidservants over the years and have been closely involved with them and their lives, and it is to some of them that I now turn. ${ }^{\text {iii }}$

\section{Stage 1: the Fear of Contamination}

Among the first servants I had during my initial fieldwork was a maidservant named Shyamdulari. She came from a family who rolled cigarettes called biris for their income. She was poor and low caste. I realized quickly that my relationship with her was destined to be different to those of other servants I had encountered in my past, pre-fieldwork life. These others had been merely professionals doing a job, hence two dimensional for me and lacking in any social and human depth. Shyamdulari was exactly the kind of person I was actually studying.

I made the following observations. Artisans, given their occupation, were carefree and knew that they were so. They could tell the interested researcher like me of their concepts of mauj, masti and phakkarpan (carefreeness, joi de vivre). They liked to be masters of their time and scoff at rules from external sources. Almost none of them took up service jobs in shops, homes, or factories, avoiding them as hell-like or jail-like choices at the very bottom of the ladder of choices when impoverishment struck. Naukri, as service was called, meant literally to be someone's "servant", to have a "master" controlling you. To earn four rupees a day instead of ten or fifteen was acceptable, but not to lose one's freedom over time and action by doing naukri.

Shyamdulari was such an artisan. She was a lovely, interesting person but a poor servant. She arrived late and wanted to leave early. Many days she did not arrive at all. She would sit and dream, or chew tobacco, or disappear. She did her jobs at snail's pace. She had a sense of humour but I got tired of sharing jokes with her as the work was left unattended. Her not doing her work meant my not doing my own, because hers was more essential so in her place I would have to do it. 
Basmati followed Shyamdulari and took over charge of crucial domestic work, including watching the baby in the mother's absence most of the day. She was a wizened old woman, who miraculously grew younger over time, even as her mistress definitely grew older. She was drawn from a suburban village, a village of ex-fishermen and new sari weavers, and was an artisan to the core. She loved poetry, music, dance, and colour. Our baby was probably more comfortable with her than I had bargained for, and while grateful for the physical latitude this gave me, I was also, I realize in retrospect, resentful of the local, indigenous socialization my first born and precious child must have been experiencing.

Basmati assessed her indispensability quite accurately and bargained effectively to raise the level of her salary and vacations, until we reached a point when she was, as it were, in pensioned retirement, back in her hut in her village attending to pressing family matters, visited by us periodically to plead our case regarding her return, re-appearing periodically to keep the fact of her indispensability intact — and all the time able to demonstrate aesthetic sensitivity, warmth, love, and even loyalty.

Of course we could not fine, or fire, her for her absences because she, and her whole village including the headman, was so inexpressably poor. The huts made one dry mud continuum with the earth. They were almost totally bare inside. She stayed young because she was not old to begin with, and only looked wizened like so many poor people who look much older than their age. But the poverty was difficult to relate to in an uncomplicated way because of her “exploitation” of it. I was silently enraged that people like her felt no need to have a work ethic at all. Silently, because the dawn of such a feeling surely put me on the side of the "outsiders", the merchants who sneered at the backwardness of weavers, the visitors to the city who hated its non-purposeful philosophy and meaningless zest for life, and the officials who for over a hundred years had been writing about its chaos and vulgarity. I did truly feel drawn by this zest, chaos, and craziness, but was appalled at its destructiveness. It was not a problem with wither her or me. It was a structural problem where for the beauty of her world she had to be who she was, but for the representation of this world in the academic world I was part of, she needed to do her job in order for me to do mine.

Apart from carefreeness, artisans, like every other class of people, had their own culture of food and drink. Their favourite dishes were very interesting to me and I noted their high use of pepper, red and green chilies, mustard oil, and many spices. I myself never ate like that nor did I want to start. Our cook for one year in my second round of fieldwork was a mother-daughter couple from a wood carving family. Indeed they were the mother and daughter of my star informant, Tara Prasad, who had died suddenly, leaving them with nowhere to go. The mother, 
Lilavati, had been a housewife so far with little knowledge of anything outside, and the daughter, Mangra, a school dropout of twelve years. I offered them a job, and used the weapon of our honorific kin ties, Lilavati my sister-in-law, Mangra my niece, to ensure that they could not refuse. I knew that I would "treat" them more kindly and pay them better, than wherever else they could find a place with their limited knowledge.

The year was spent in an ironic reversal of the previous four years of research. From teaching me about their culture, they were now being taught my culture. They had been obstinate and strong-willed about what they believed. Now, it turned out, so was I. We had frequent clashes. Thanks to Mangra, who unselfconsciously proved one of my main dogmas that only children can really learn anything, the clashes were over quickly without a residue of resentment. A frequent one, for instance, was about the making of tea. They valued a heavy creamy sweetened drink that had turned tea leaves to poison, as I saw it, by boiling them (a drink unjustifiably popularized as “chai” in the USA today). I could not and would not accept it. As a drink it was probably all right, because whenever I had tea in someone's house, this is what it was. But as a staple of life and a symbol of the self, this sugary soup was oppressive to me if served matter-of-factly to me in my own house in lieu of my steeped just-so tea.

I call this section "Fear of Contamination" because the only lesson I drew from these experiences was that one must keep servants and informants separate, and the two relationships free of each other. That there was a part of me that was the professional, who would listen patiently and respectfully to all that my informants valued and did. And that there was a part of me which was my own and which would keep her preferences to herself. But a servant is a very intimate category. One needed servants. They tended to be around in intimate places for intimate jobs. I quickly realized that almost anyone I got in my small town melting into its rural suburbs would not only have to be taught the job she was being hired to do, but that she would then proceed to teach me about my heretofore ambiguous relationships between me and my culture, and between me and her culture-both of which I had foolishly taken for granted so far.

Why “ambiguous”? What is wrong with compartmentalization? Since we are talking about seemingly trivial things like tea, this is not self-evident. I mention the tea case because it marked the beginning of my awareness on the issue, but the question is a much weightier one of relative choice and power. At one level we are all the same: we enjoy walks, friends, conversations, music, and we all enjoy life to the hilt when not in sorrow with the hearbreaks of death, parting, longing, frustration and confusion. But there is a systemic inequality built into the equations: Shyamdulari and I; Basmati and I; Lilavati and I. We can all of us be free and happy, full of mauj 
and masti, exercising our free will. But only I, and not Shyamdulari, Basmati, or Lilavati, am additionally empowered through the power of literacy and then a multi-faceted education.

Are 'they', the 'unlettered' informants, and 'we', the educated scholars, then alike? Is not the difference of education the greatest difference altogether for what else is the difference between me and my maidservant except that I have had a certain education and she has not? Would Lilavati ever have been a maidservant if she had had an education? And if she has not had the privilege of an education, is it not because of the History of the nation, deriving from the History of the world, with its contemporary chain of schools, ostensibly open to all, but not in fact?

It is difficult to tolerate the language that speaks of informants and scholars as 'they' and 'us'. iv If not immediately then after some time in the field all do indeed to appear equal, although not the same (Rabinow 1977). Yet, there remains the crucial inequality of education. If scholars and informants share the same interests, but the scholar is better educated, and is empowered by her education, which indeed creates the inequality that she lived off, how can she not acknowledge it? How can the informants not be called what they were, as heretofore denied this education? And how can they be denied this education further?

Is not, then, the only solution for a private individual to undertake some education, on however small a scale, to reduce the inequality, by however tiny a notch? Because, once the realization presents itself, to not act is of course to act, in preservation of the existing system. In my case I did not act because I considered myself fortunate to have discovered the world I was writing about and would have done nothing to jeopardize being the unprejudiced observer of it. The consideration that my informants were 'poor' in terms of choices, or mobility, or power, certainly crossed my mind often but was a set of thoughts put aside in the interests of a larger, elegant deconstruction of their culture. To be afraid of these considerations as a contamination of my work, and a contamination of their culture, when the worst possible contamination was entrenched already, created an impasse for me that led to the next stage.

\section{Stage 2: the Fear of Domination}

The British had a healthy fear of servants. Behind their very masks of inscrutable servitude, servants' obedience probably hid deep revolt. With the end of colonialism and other social changes, masters and servants continue but not with the same meaning to those names. They can often not be differentiated, and the recognisably unifying factors between masters and servants increase at every step. 
Both Shakuntala and I were aware of this, that we were basically one people, I her 'didi' or older sister, she my younger one. But both were attuned to niceties; it would be difficult to say who the more, but she certainly at least in speech. Thus, her demeanour towards me was, appropriately as she would consider it, "Didi, you are great. You have money, home, health, education, job, fancy possessions, and status. Look on me kindly, who have none of these desirable things." My demeanour towards her was, "Shakuntala, you old poser, get on with your job. I know you people well. You, specially, need not put on these stage effects for me." She was single and earned well, lived with her family so spent all her earnings on clothes and makeup, was a smooth talker, flirted with all men, and had supreme self-confidence.

Shakuntala also came from an artisan family. Her father and brothers were blacksmiths. Her mother cleaned grain for a living. Her sister and she herself made extra money by stitching and mending. Shakuntala displayed another important characteristic of artisans: she learnt fast those things that had to do with the eye and the hand, she had a knack for crafts, and she did not feel rooted in a particular manufacturing profession but felt that all crafts were hers to master as and if necessary. A little studied craft is that of bodily decoration. Shakuntala specialised in that.

To my chagrin, not only was she always turned out like a cover girl, with plucked eyebrows, cream and lipstick, coiffured hair, and carefully chosen clothes, she constantly lectured me on the virtues of being like that, and my two daughters on the brink of teenage. In my opinion Shakuntala was the perfect example of the woman in a man's world, one who judges her worth by the gaze she can attract from men, who consumes whatever the cosmetic and clothing industry present as necessary and desirable, and who have no thoughts of an independent mind which may possibly reject some of the premises of this male misogynist industry and this world.

I could have treated her merely as a professional servant, restricted my interactions with her to her work, despised her in the privacy of my thoughts, and got along with her and myself. But, as I said, a servant is an intimate person. At this stage, stage 2 for me, I also became aware that it was not all right to compartmentalize. To pay Shakuntala a handsome wage which, if smoked away as by Shyamdulari, was somehow sweet and tolerable, but if used for a hairdresser's and L'Oreal and Max Factor by Shakuntala, was not, had to be thought about. Her very presence in my home for some eight hours a day meant a level of interaction where our different stands on women and their bodies could not be ignored.

But Shakuntala was both more determined in her beliefs than me and more certain of her right to hold them. I was often lost in reflection and questioning. She was totally sure. I became resentful of her power to dominate. I became downright angry when I understood fully how her certainty was in direct proportion to her ignorance. 
Her slavishness to new products was all the more objectionable because she could neither say their names nor read their labels, but recited their virtues like scriptures. She was totally illiterate. She seemed to manage fine without literacy and, disregarding my mild strictures on the subject, constantly increased her aura of self-confidence.

With all kinds of doubts and questions in my head, I expressed tolerance for this different way of being and let her free to indulge, as I called them, in her own follies. But they had a short life. When I saw her last year, she was visibly older and more tired. Having left our employ four years ago, she had free lanced with the things she knew best: stitching, mending, hairdressing, make-up, massage. Now she would be employed for three months at a beauty parlour, now for a day at a wedding. I think I should have pushed her more. Somehow forced her to be minimally educated. Somehow bullied her into learning more about what a woman can be. Somehow exposed her to other job possibilities and helped her into something. I should have owned up to the recognition of her as innately intelligent, self-'educated' and 'wise', dynamic as a learner, and a powerful resister to the glib, elitist discourse of the global cosmetic industry. But I was afraid of the domination she regularly practised on me and very uncertain about my own dislike and possible domination. I knew that I wanted to be fair to her but the uncertainty lay in the nature of this fairness. Should I let her be as she was because she was, after all, only related to me by being my servant and from the same class as my informants, that is, should I let her culture be in peace? Or should I treat her (as I would like to put it), with more respect, as I would someone from my own class with whom I had such long, intimate ties, say, my friend, and engage her constantly in a reciprocal exchange of ideas even if she did not seem to understand my ideas I know that different anthropologist would not have bothered, would have been interested and amused by her, and would have written about her with irony and delight. But she, whatever fodder she might provide for writing, was and is not destined for a comfortable life, mostly for structural reasons to do with the inaccessibility of education. If anyone could help her, which is always doubtful, it would be someone like me, because she did respect me in her own way. But I did very little because I was angry at her domination of me, and afraid of similarly assuming a role of the dominant with her, rather than that of a non-interfering, supremely tolerant intellectual being.

\section{Phase 3: the Fear of Modernization}

I realize that all my readers' sympathies will be with my informants/maidservants. That is because I have made it so. Like most people in my position, I recognize myself as a product of a capitalist world system and am afraid of its percolation into my innermost being. Therefore when 
I see other sensibilities and priorities I rush to elaborate on their many riches. There are, it would seem, aesthetic, philosophical, and political justifications for doing so. Plus in a clash between one's own culture and another's, it is the latter that deserves more space.

Yet I am haunted by the condition of my servants/informants. What does it behoove a woman to be carefree and happy if she does not know enough about her body and her rights visa-vis medical experts to claim an averagely long life and steady health for herself? We may not have to deal with the spectre of sati on an everyday level any longer. But the pain of the subjected body remains, subjected by ignorance which is more elusive but as domineering as more tangible workings of patriarchy. Anger at this everyday pain is therefore equally deserved as by the extreme case of sati. I do not have statistics at hand, but all the poor women I interacted with spent staggering amounts on doctors and medicines and in no case understood the treatment they were receiving. These amounts were proportionately about fifty to a hundred times more of their incomes than I ever spent on medical treatment; thus if I spent 1\%, they spent 50 to $100 \%$, and even got into debt. The qualitative data I have documents that they speak of 'pills' (tikia, goli), 'injection' (a word incorporated into Indian languages now), syrup, all summed up in a folded piece of paper tied up in a corner of the sari called the purja, the prescription, as if these were fetishes. They have magical properties and whether they work or not is as impossible to predict as in the case of rituals, but they are all equally targets of faith.

All my maidservants spent and behaved like this. I am thinking specifically of Shanti, wife, then widow, of a mason, who will be in debt all her life because of her misguided treatments, and Kanti, wife of a rickshawalla, who has lost her youth, energy, and beauty in a few years before my eyes from popping any kind of pills the neighbourhood doctor prescribes for ailments that probably deserve no pills at all.

The ignorance of these women is produced because of a certain structure of relations in which they involuntarily participate. It includes the hospitals and clinics, and the rows of pharmacies outside the hospitals and clinics. Equally it includes the universities and colleges, percolating down to the schools, where even if they send their children to at least the elementary sections, the women are always outsiders because themselves illiterate. An illiterate mother will never go to a parents- teachers meeting in her child's school, or interact with it in any way; she fully expects to be scolded or even thrown out of the premises. Or, if she goes, she goes as a supplicant, ready to accept whatever is handed out to her. The structure includes the law courts where many uneducated people circle under the gaze of various kinds of legal and semi-legal middlemen, in each case as supplicant grateful to receive guidance. It includes all government 
offices and, now, non-government organizations that work with, patronize, or bypass to various degrees, the poor.

The ignorance of these women is produced actively in interaction with these structures of knowledge and their practice of power. Of these structures the scholar is an inextricable part. The poor woman is there because the scholar is there. The same world that has produced the academy and its brilliance has produced the poor woman-subject and her ignorance. This world, with its medical, legal, and educational institutions, has produced the discipline of anthropology that would construct the (poor, ignorant) woman as informant but eschew any aim of changing her as a result of the encounter. The changing, the education, the self-improvement, the widening of horizons, the final achievement, has all to be the scholar's, and not the woman's.

On a calmer level: a divide between indigenous and scientific knowledge is held by all of us, whether formulated as such or not. Indigenous knowledge is concrete, enabling the holder to exist in some harmony with her environment. It matches seasons, natural materials, and familiar life trajectories. It is functional and contextual, and typically non-dichotomous and nonindividualistic, tolerant of variety and hetrogeneity. It is woman's own territory, non-official, and therefore a space for her own agency. One should approach this realm of knowledge with sensitivity and be prepared for patience to master its workings.

But what if at various stages, including when there have been years spent at this sensitive decoding and mastering, one feels dismayed and troubled? I will take the case of Shakuntala Patel (different to the beauty Shakuntala), who worked very briefly for us, and Mangra, the little girl of stage 1. Shakuntala has six daughters, the youngest only three, the oldest married but still not sent away. The mother works full time and also goes out for pleasure whenever she wants, making the point that she is dispensable to the running of her household. The oldest daughter looks after the younger ones and cooks and organizes the housework. After getting to know their family, spending time with them on various occasions and sharing their stories and jokes, I found myself visiting one day when they were all glued to their television set watching an Oriya movie that no one could linguistically understand (being Hindi and Bhojpuri speakers). The plastic bags of the whole neighbourhood were littered in their spacious compound making it, as indeed was the case with the whole village, an urban slum. The scene provoked me to voice many unasked questions. I asked about marrying the daughter off in her early teens--why? The mother said that she was herself thus married; no one argues with adults on this score. The rational reasons are that the choice of boys is greater and the dowry to be given will be therefore less, and one may negotiate, and also act exactly when one was properly ready with the dowry. No one would take an older girl anyway. It is good for the girl also because she gets broken into her new home 
gradually. She visits it for longer and longer, starting with one day, then a few, then one week, then a few....Everything continues as before, with her actually belonging in her old home, but making the transition to the new. Of course, there is a tussle. The mother-in-law and sisters-inlaw, or the boy's side, express their need of the bride and demand her presence. The mother and other family members of the bride express their reluctance to send her. Occasionally the tussle can expand into a rift with neither side willing to compromise, and the girl is left on one side or the other. The young girl begins thinking of her sasural, her married home, as her home typically when either the first child is born, or one parent or both on either side dies, or the brothers on either side separate, creating the space for property ownership and a conjugal unit.

I listened with full attention and was pleased that I 'got it'. Existing marriage practices certainly had their logic. It became only very slowly clear to me that as long as one does not interfere in the practice of child marriage, one is putting one's invisible weight in support of it. Or that one has to actually ask the question: how far may one benignly accept the practices one encounters? Shakuntala's daughter will mature to be like her mother: most probably earning, but in any case, free, strong-willed, confident of herself. She will know less than her mother. about matters such as keeping her courtyard clean. That is, if women in an 'older' system, including of early marriage, are supposedly in tune with their environments or competent in certain lifestyle practices that are benign and nurturing, there is some kind of a case. But when they are prisoners of the most perverse accoutrements of modernity, such as plastic bags, and more serious effects, then we may have no case at all. The most serious of all the effects of 'modernity' are supposedly new, smart ideas of childrearing.

Mangra, who was the raw adolescent in my fieldwork in the eighties, was the housewife and mother of maybe 25 in my later fieldwork in the nineties. Mangra's son Vijay, affectionately and in the modern spirit, called 'Vicky', has been going to school since he was three, indeed, going to schools, one the formal one, and then one at home with a tutor. This is what all aspiring families in urban India do for their children. The double pressure was perhaps partly responsible for him developing an ulcer which had to be operated on, leading him to miss a school year at the age of six. After that, the pressure on him was increased. Now he revolts against schoolwork and is condemned by Mangra as incorrigibly destructive. In his presence she keeps talking of him as badmash (a rogue), harami (a damn rebel), and sunta hi nahin hai (totally disobedient). Both her discipline and her punishment are different, and I would argue, worse, than her mother's were, because of the changed circumstances. Mangra and her husband own many more amenities than their parents did, but there is also a more tangible gulf between desires and fulfilment. The lack of desirable resources in the home--delicious meals, space to sit or play or rest in, attention in and 
out of school, money to fix the cassette player broken by the destructive child--creates an underlying sense of tension. The mother acts as if in charge, but she is also a victim. She is afraid of pushing a resentful child; she shares the child's frustration; she cannot admit her mistakes. Hence, her inability to refuse the child anything, to actually control or discipline, her ceaseless personal comments, her consistent blaming.

Abu Lughod (1993) narrates her experience of mother and children, including the mother's indifference to the children except to shoo them off or scold them or slap them. This helped me put my problem in words: why may not the scholar interfere? Interference could take numerous forms, starting from a casual conversation during a visit, to the rather formal extreme: an interactive workshop for neighbourhood mothers. The categories 'workshop', even 'mothers', and certainly the idea of interference in 'mothering', all seem foreign and strange and totally out of place in an anthropological essay. But why are they? Government and non-government organizations have been experimenting with them for years, and when interactively conducted, produce some results. I suspect that scholars would not like to be put on the same platform with them, perhaps to be judged by similar criteria of success. Women's magazines for middle class readers in India regularly teach about bringing up children. Lower class children and mothers are aware of these lessons, albeit only of their more marginal messages. Thus Purnima, poor and illiterate maidservant and proud mother of a son, like Mangra, told me she knew how 'birthdays' should be celebrated. "You put on a conical cap, you have balloons, you get a cake with icing, and you sing and give presents." To the extent that they can afford it, 'they' will also try, once they have heard of this system, to copy it. Why not?

So, there could be discussion of, even exposure to the arts and sciences and philosophies of, or any other problematization of, child rearing that dealt with more substantial issues of selfesteem and disciplining rather than merely birthdays, although those too are important. Many such good and bad discussions already fill the air and impress everyone variously, to say nothing of more insidious marketing and consumption structures. If the scholar's fear is that by discussing with mothers how 'to mother', she will be violent and complicit with the worst in modernity she could debate whether the best favour to do the people (not 'the culture') is not to respect and accept their wishes for modernization and share with them some of the spoils that we, the "more modernized people have accrued in spite of our critical attitudes towards it. Modernity, after all, has largely created the problems, but also empowers by teaching critical techniques to produce resistance. Modernity makes available discourses of knowledge, including some that deconstruct it. That is how I learnt any 'post'modernity, to give the devil, modernity, its due. To not share the 
discourses available to me with Mangra, or Shakuntala, or Shakuntala's daughter, is to live off their problems.

At the end of the spectrum are cases that are surely more troubling still. Parvati worked at two jobs, in our home and elsewhere, because she had to feed and clothe the family. But the long hours of work meant that she could not watch her son. Over the years of eight to twelve, he progressed from being merely naughty and missing school, to being incorrigibly indisciplined, to being a prototypical school dropout who looked, talked, and behaved rough, gambled, and got into fights, and had/has a very dim future ahead. Parvati also suffered abuse from her husband. Of these multiple problems, I may have no resource to tackle many, but I certainly cannot claim that about the problem of her son. I am, after all, studying the precise topic of education and children. I have devoted my adult life to the study of Indian history and society. I teach and speak as an expert on the subject. What is it that keeps the problem of Parvati and her dropout son outside the purview of this knowledge and expertise? What is my excuse for not knowing what to do about this, and if I know (which I surely would make it my business to know if the matter mattered to me), why do I not do something with this knowledge? I have increased my store of learning immensely thanks to Parvati. She, in turn, continues not only to know not much more after contact with me, but to have this son who she has not been able to keep even in school. Because of me, I feel like adding. Because I do not interfere in her life out of my fear of modernizing her. The same is true of Shakuntala, Durga, Mangra, and their children, all of whom have educated me, but not I them. Not because they do not have the will to learn, but because I imagine that only I do. In doing so, I am not being 'myself'. I do not extend myself; I do not make of myself and my presence in the field all that it could be. Certainly they learn at their own pace, but as far as my positioning goes, I do not co-operate with them in their move, I do not give of myself.

\section{Phase 4: the Fear of Politics and the myth of non-interference}

The fear of modernization could more accurately be called a fear of politics, based on the 'myth of non-interference'. As a term used to describe Indian colonial-nationalist policies after 1857, this myth presupposed a private, domestic, typically religious or ritual space not influenced by colonial rule (Sinha 1995: 141). There was, of course, no such space, inscribed as all spaces were by the same legal and administrative codes, infused by the praxes regarding land, property, migration, occupation; and written over by colonial discourses of identity and public-private separation. There was no way in which the colonial presence and rule would not 
impinge on the 'private', and the defence of this private, typically woman's sphere was a convenient strategy of the nationalist elite to entrench patriarchal institutions and practices.

There is a similarity between that situation and the situation today where there can be said to be nothing uncontaminated by modenity and the nation state.. yet many classes of men would defend their rights to run their affairs as they will away from 'interference', either of the government as in the Shah Bano case (e.g. Das 1995), or of voluntary reformers. Many women would themselves claim their right to their separate worlds and from quite transparent platforms of ignorance, or echoing the voices of patriarchy, position themselves as inferior and objectified. Scholars are not colonizers in either material or discursive ways. Yet they seem to buy into the discourses of contemporary nationalist masculinity and patriarchal structures at several levels, some of which are apparently understood as 'women's culture'. They would not interfere even in their capacities as feminists apart from their feminist scholarship Thus they would collude with patriarchy in a way similar to the collusion of colonial and nationalist masculinity.

Colonialism has left many kinds of legacies in South Asia. Today there are many questionings of an involuntary condoning of social inequity in the name of culture (including by Asad 1975, Hatch 1983, Gellner 1985). Yet, such is the legacy of colonialism that there is a split between not only classes or cultures but between worlds. As an educated member of the western/global world the scholar feels strangely reluctant to interfere with local cultures because she may be acting like a colonial. Even when she can see quite clearly that the situation demands interference on humanitarian, feminist, political grounds, yet such is the whole structure of this colonial discipline of anthropology that a separation is sincerely maintained between what we the scholars prefer, need, and tolerate, and what we are happy to report them, the informants as preferring, needing, and tolerating. And not everything can be lumped together. There are practices, the larger number of the total, which are best left alone. There are only some that need to be argued and debated. There are the few that exceed the pale of tolerance. Yet, for these last, the scholar muses, maybe she simply does not understand them, maybe she needs to work harder at her exigeses or even simply data collection and interviewing? Maybe there is justification for hitting children or abusing them or neglecting them? For not educating them, getting them employed, or marrying them off? if we were to seek to interfere, might we not come dangerously close to implying that they are inferior in some way to us?

Colonialism has truly polarised the world. Diversity is surely good, plurality likewise, variety and heterogeneity, yes. But simple minded tolerance in the excuse of nothing but tolerance itself is another matter. A lack of a practising politics is another matter too. And another matter yet is an academic technique that wins as reward the best in modern amenities for 
the scholar and her dependants, from electricity and gadgets to longevity and top health care, to say nothing of freedom and mobility, while leaving the informants maximally untouched, as close to possible as we found them, that is, without any of the afore mentioned benefits.

Colonialism has taught us to forget how to discriminate between levels of practice according to how they matter for life. Everything is lumped together as 'culture' regardless of how lifethreatening it is, how resilient it is, how hierarchical and contested it is, how precious or dispensable it is. In the name of culture, we see differences where none may exist. So I go to study village women because they are nicely different to me. But if I teach them something I happen to know about childcare, say that something called paracetemol exists (a knowledge that could save babies' lives and mothers pain, just like babies and mothers anywhere), I am (a) not going to succeed in changing their religion overnight, so that fear need not prevent me. (b) If I and such as I, do change their religion in the long run, we are simply some of the many circumstances that regularly play a role in history to thus keep everything in flux, and we need not rate ourselves any higher than that. (c) If this argument seems suspiciously like what the colonial state could have said in its own defence, as part of the larger aim, “civilize! reform! emancipate!” we have come around exactly to my argument: that such is the legacy of colonialism that the very fear of seeming to resemble colonialism prevents us from taking necessary action. But (d) a recognition of equality means seeing that we do not in fact dominate, that they are capable of sifting and judging for themselves and should be respected as being capable of choosing to have our advice and not simply of having it forced onto them. We need to shift the focus from us to them. That is what would make our interactions with them different to the work of missionaries, colonials, and modernizers.

We would also almost certainly do a more nuanced, richer ethnography, as we would uncover layers of thought that were left untouched when we only probed the surface features of 'culture'. A difference in the observers' view and the informants' more pragmatic, engaged view has occasionally been suspected. A simple example is Engels report (1996: 126) that Indian women explained their poor birthing conditions as due to specific reasons, whereas Europeans would ascribe them to customs and traditions.

Am I suggesting, then, that there are certain universals, such as death and pain, freedom and pleasure? Is Veena Oldenburg correct to make her sweeping claim that there has never been an authentic sati? (Oldenburg 1994) Maybe we do not need to be able to answer this question and it is still too early in the stage of human knowledge to know about universals. Maybe it is enough that there are different versions of some things that are pretty universal, such as respect for human life, avoidance of unequally experienced pain, respect for the environment; that there is 
something describable as structural violence (Farmer 1996).. Maybe it is possible to lay our excited conscience to rest by reminding ourselves constantly that there is and should be a give and take, that if we teach, e.g., a fact about cleanliness, we are not necessarily emulating our colonial forebears who believed that all their beliefs were superior without the benefit of enquiry, but we are indeed keeping up a complex, ongoing enquiry, are forever willing to learn and change, retain our irony and scepticism, but are willing to take the risk of being put in a mistaken role meanwhile for what may be certain gains, such as the prolongation of a life. Is it more important to preserve a culture, after all, or a human life?

And why do we have this notion of preserving a culture rather than boldly negotiating with it? Is it not a (convenient) fear of politics?

\section{Phase 5: The Fear of Poverty}

Why do I not speak my mind out though? The so-called fear of politics is in fact a fear of poverty. I went to the house of Kanti, our one-time cook, whose husband drives a rickshaw, his brother weaves saris, and the other brother is a Home Guard. Going through the muddy main road of the predominantly Untouchables' neighbourhood, now broader and well lit thanks to the World Bank and Chief Minister Mayavati, champion of the Dalits, then through the narrow lane bursting with people, to reach her house, I turn the corner and find myself in what seems an idyllic village centre with a pond and spreading tree and houses in a semi circle all around, some clay, some pakka. "How pretty!” I exclaim. “There’s even a pond!”

“Pond!” laughs Kanti bitterly. "It’s not a pokhra (pond). It’s a pokhri."

I am reluctant to confess my ignorance of the exact difference between pokhra and pokhri, what an 'i' can do, in short. But I grasp the difference right away. It's between a clean, pretty body of water such as it seemed to my short-sighted eyes in the gathering gloom that it was, and a dirty, somehow-collected body of water that no one wants. Indeed it is wanted so little that everyone is trying to fill it up. The way to fill it up is, by common consensus, to throw all garbage in it. Pokhri bhari ja rahi hai, everyone tells me in the passive voice: the undesired pond is being filled up.

The homes I have passed in the lane are so small, so dismal, that I am afraid of what I will find at Kanti’s. Yes, I am actually afraid. What will I write? How will I express my sorrow and my sympathy, my sense of a history gone wrong, and regret at being at a simple receiving end of the spectrum? But I am pleasantly surprised. Kanti’s is a brightly lit single room of concrete, new and clean. The floor is so clean you could mix batter on it. Indeed the cooking is going on, on it at that very moment. Rice is done, dal is on the fire, bhindi is being chopped. All around 
are shelves built into the walls lined with the Sunday glossies from newspapers. Canisters are kept in one, gleaming pots and pans on another, stainless steel plates and bowls on the third. A new wooden bed is on one side; a bicycle at its foot. These are symbols of prosperity; indeed everything in the room is. I feel distinctly foolish to have mentally and outspokenly ignored the efforts of those, like Kanti, who provide themselves with a clean, safe environment, pleasant with light and air, comfortable with the amenities for rest and pleasure. This is what Kanti is very deliberately doing when she covers her shelves with the glossies and stand up her steel ware, museum-like, against it. Or, when she buys the bed and puts it in her room in a way that indicates it is partly an exhibition piece. To be precise, she did not buy the bed. She negotiated for it, probably very strictly, with her daughter-in-law's family. This was of course, better from the anthropologist's point of view as data regarding a cultural practice, but 'worse' from a lived-in point of view in that women are commodified.

Kanti's niece sat in her place to cut the okra and entertain me while the aunt went off to get me appropriate snacks. Usha was in her early twenties. She had born three children, none of whom had survived. The case of the last was typical. Usha had been 'full of water'. She was 'like an elephant'. But she felt she was actually only swollen full of air. She had no blood. Her baby died upon being born (being deprived of the mother's blood) and she was given up as dead. Her coffin had been sent from her natal home. People were weeping and crying. Then they took her to the hospital and about three buckets of liquid were drained from her. Blood was pumped in: khoon charha. It was like coming back from the dead.

And the other two babies? I faintly asked.

They would be delivered at seven or eight months and die forthwith. Usha looked unhappy but resigned. She had delivered all her babies at home, in the presence of a dai. In books arranged under Stri Shiksha (Women's Education) in the local archives, I had read that women in the nineteenth century were ignorant and uninformed about pregnancy and childbirth and often made grievous mistakes, fatal for their babies. Dais were likewise uneducated and were trusted blindly more than they deserved. Some concrete examples were given. Apart from common problems such as tetanus, from which there were as many as 50,000 deaths a year less than a hundred years ago, there were less tangible problems regarding diet, nutrition, and so on. If a child grew up less than normal in certain ways, it could almost certainly be blamed on the ignorance - the satisfied ignorance — of the parent.

Parents just like Usha. Her husband caters and cooks for weddings. He is a halwai. The work is sporadic, the earnings feeble. He hardly provides enough for the two of them to live on. They have one room on the edge of the filthy pond that is being filled in with garbage. They 
have no electricity. I am full of pity. It is the double blow of the lack of education/knowledge: not permitting her to get a job (except always as a maidservant) and not permitting her to have babies.

Then there is the more ambiguous case of Kanti herself. She married off her son; one would think a very important person, judging from the fact that as dowry he received a bed and bedding, a cycle, a T.V., a watch, an almirah, clothes, utensils, and cash. When I exclaimed, Kanti said, determined to be non-defensive, “Well, they are giving it all to their daughter, aren’t they. Is it to us that they are giving?” At which her neighbour, sitting alongside her, murmured matter-offactly, "Well, you get the cash don't you." This second person herself had a young son soon to be of marriagable age, presently training to be a carpenter, and she looked studiously practical about the topic at hand.

A vision opened out before me of how women were themselves powerless, from the days of Manu at least, and of how their only power lay in their motherhood. So they not only lavished all their care on their sons in order to be revered and obeyed the rest of their lives, but worked in numerous intangible ways to support the ideology that decreed that a son should worship his parents, and specially his mother. Manu and his fellow rishis all proclaim that women are good for nothing but to serve their husbands, and in the same breath, that it is the duty of every male to put on the highest pedestal his mother. For those women who could not protest the first of the proclamations, which means every woman, it was a boon to have the second idea.

But although there is such a thing as a prescription for women and for femininity that goes beyond class and location, there is more emphatically a prescription for poor women and for uneducated women. The noose tightens the more uneducated the women-Subjects are. I know in my guts that poverty, or class, is bigger than gender. I can glimpse how the recognition of poverty, and the fear of poverty, could lead one quietly to take refuge in gender. How much the female researcher and her female informants could share in spite of differences! Why, then, we should talk about the woman scholar and her manservants, or the man scholar and his servants, men or women. If one were to do it (it would have to be done elsewhere, not now, here), one would not, I suggest, significantly revise or reverse any of my claims in this essay. The presence of men in the argument, as either of the two Subjects, the Scholar or the Servant, would still lead to the stages as I have described them: the Fear of Contamination, of Domination, of Modernization, of Politics, of Poverty, and then, perhaps, of Love. In my analytical model, a manservant would show himself to be first a servant, then a man. A master would turn out to be first a master, then a woman or man. 


\section{Phase 6: The Fear of Love, the Victory of Professionalism, and the Pursuit of Postcolonialism}

I love my maidservants/informants. This is a confession so difficult to make to anyone I know. Colleagues look embarrassed, and Indians, particularly those who have experienced similar servants, profoundly sceptical. Moreover, to my own embarrassment, there is a clear resemblance in my statement to the genteel attempt to deny class, and protest kinship—- $\mathrm{Oh}$, my servants are like my family members.”

These women do not all love me, not at all. There is a Chamela, who lives in a broken, one-roomed house, but beams with pleasure when she sees me coming down the street and rushes to pull me into the room and bring me tea and dalmoth, and protests when I am ready to go; all this so consistently for so many years that I know it is not only the good manners her parents taught her but her own feelings. There is also a Lakshmi, living in only a slightly better one-roomed house with a fatherless child and several other discomforts, who definitely does not brighten up on seeing me, and on the occasion of my last (intrusive, as I understood) visit was reported as having told her colleague, "Does she think she has bought me?” And there is a Parvati, whose feelings I am not sure of, except that she humours me in my various efforts but consistently follows her own different path, while all the time concerned and affectionate about me, indeed, definitely condescending.

'Love', overused a word as it is, may be the wrong word. My informants/servants/friends (if I dare to say it) haunt me. I cannot even take an aerobics class in the USA without plotting in my mind how I could teach them some aerobics when I am next back there, how they would laugh and joke, but also how some of their aches and pains might disappear. This is a pleasurable haunting, not a horrifying one. It enables me, I am beginning to feel, to suggest what I have vaguely and vainly pursued from the beginning of my scholarly career: how to construct a postcolonial methodology.

There are authors interested in the intersection of gender with colonialism (Mohanty 1988, Sharpe 1991, Suleri 1992), whose work I see as inspiring, but limited in one way. They see the main encounter as an 'East-West' one and are troubled by the West's negation of, blindness to, homogenization of, and consequent distortion of and fallacy about, the East. They correctly see that the whole 'culture construction' of scholarship, and the common sense view of culture and everyday life of the West, is formed and imbued by the colonial encounter, but never admitted as such. To fight this unjustified distortion of history is certainly an important task.

But these scholars, in so far as they see this fight as leading towards a postcolonialist resolution (and the literature on postcolonial approaches is vast; see specially Frankenberg and Mani 1996, King 1999, Loomba 1991, McClintock 1992, Said 1989, Shohat 1992, Spivak 1999). have too literal a reading of difference and its negation. Postcolonialism would have to be an 
active going beyond colonialism, not merely be a description of it.. It is a labour, a construction, as I see it. Colonialism does not characterize merely civilisational, military, social and epistemological encounters between nations or states, but also those of class and gender within a nation, state, or even community. I find institutionalized scholarly research, particularly the anthropological method, fundamentally colonial, which is not to deny the fact that there are many more sites of colonialism that are larger scale or more injurious (Tenhunen 2002). Scholarly research, however, is what concerns us today.

I have argued that the product of these class formations in the case of one individual scholar doing her particular project is demonstrably characterizable as colonialism. In doing so, I have focused on the relationship of mistress to servant, not only because I experienced it, and made it an object of reflection and study, but because it highlights something in class/national difference that is obfuscated in less explicitly hierarchical interactions. Further, it is important to look at the servant case because the intimacy and simultaneous tension it produces highlights another feature of the informant-scholar relationship not always visible. Let me take a moment to expand on this.

I said at the beginning that the scholar is the mobile one and the informant the static one. But in the master-servant case, the scholar is the one who sits at home and waits, literally, for the servant to appear at the agreed time, and the servant is the one who takes off and disappears on a daily level, and one day simply leaves the job. Why else do you think I had some twenty maidservants in twenty years?! This mobility and exercise of agency and the scholar's reluctance to admit it is a reflection of the scholar's reluctance to admit how much she actually does not know about her informants, how they have eluded her, and may be even betrayed her, how many she dropped and changed, and why.

But a greater reflection of the exercise of the servant's agency is glimpsed in the case of one of the most famous servants of all, Jeeves, and his dreadful master, Bertie Wooster (as in Wodehouse 1993). Jeeves the butler is the intellectually sophisticated one, and we would rather take his side than the inane, rich, and insufferable, Bertie's. But who is really cleverer, Jeeves or Wooster? Some would say that Bertie Wooster is. He is the narrator, like the anthropologist, and he has to have two voices, or two mouths. One, to say those silly, brainless things. The other, to present himself readably and credibly as someone who would say these things, making it so that we respond in the way intended. Like the anthropologist, but in a different style, he says winningly, “Wow, Jeeves is really clever. What do I know?” Note, he always does well.

By which I mean the moulah. Bertie has not only enough, but he has enough to keep a mastermind like Jeeves at his elbow, murmuring, "Yes sir”, and "Very good sir.” The moulah never gets transferred. Now, there is a delicate question of excess here. Bertie talks and exclaims 
too much; he has too much voice. Jeeves is imperturable and says almost nothing. Can he, as the subaltern, not speak?

We know this to be absurd because he is the key figure, the one who makes the story happen. He chooses not to speak because it suits him. He does not need to speak; he suggests; and his master voices his ideas. Another side would say, then, that it is Jeeves who is the cleverer. Very likely he even keeps his own journal, with his narrative of what is transpiring. As for power, he has it twice over: one in this silent, invisible form, and the other in the form of the expressions Bertie voices on receiving his subtle communications.

This particular case of the master and servant seems on the surface analogous to the relationship of the scholar-master-narrator and the informant-servant-narrated on its ambiguity. But the real analogy is in the impossibility of a resolution of the ambiguity of who has the power, the intelligence, and the voice. My suggestion is that we will never know, that we should be content to let the ambiguity stand, and that we should work for a postcolonial methodology in which there is always this tension of two subjects, and a division of power.

I find the discussion of master and servant useful because it thus mixes up the categories of 'master' and 'servant'. Let us anthropologists also do so, if we can. Let scholars in the field serve their informants, not have the informants only serve them, the scholars, with data on their lives and raw material for their learning. Let the scholars be at the informants' service in whatever way needed by the latter, but at the most basic, with simple, necessary education. Let the scholars produce something useful in the field, and not merely consume. Let them educate and not merely get educated.

My arguments then have echoed and re-echoed the proposition that one must understand the informant's situation beyond the definitions of the scholar, and expand the scholarly activity to deal at all time with two Subjects. We would then recognize the Scholar as the Subject engaged in "authoritative theoretical production" (Spivak 1988: 66), but also understand the other Subject to be not 'silenced', as if 'silence', or its opposite, 'speech' or ‘voice' or 'authorship' had a transparent allusion to something fixed and recognizable, and we had to do no work to distinguish and recognize it (Shree 2000: afterword). That it was only one of the Subject's, the scholar's, prerogative to insist on the proper definitions of 'speech' and 'silence'.

Postcolonialism, then, should be the effort to forge methods in our disciplines that can preserve the best in them while moulding them in ways to go beyond their founding moments in colonial sites which seemingly formed their (arguably) core approach forever. In proposing this additional labour for the scholar where she attempts to understand the informant beyond the formulation that she brings with her to the field, I am also pushing for my preferred strategy of 
'education'. By this awkward term, which suggests activities forced and unpleasant, I mean in fact a very wide discourse and a huge range of activities. The discourse of education in South Asia includes the idea that people are fundamentally changed by their education, and strange though the idea may seem to a classless West, it is important to take it seriously from the South Asian case.

It is a frightening prospect to undertake any educational work and make the interaction truly two-sided. Imagine the grubbiness of poverty, slums, disease, ignorance, small-mindedness, all not disturbing so much for their material difficulties as their intellectual disturbance to our emerging--existing systems of knowledge. Imagine not being in control and being actively resisted. Imagine not being able to just step off, but having a burden to carry. Then imagine the awkwardness, worse even than all the above, of the self consciousness of finding oneself with the grandiose aim of trying to change the world.

But that need not be the aim. The single aim need be only to be a better scholar and do one's professional job better. All that I have been saying is in the interest of furthering scholarship. My point is not a transparently ideological or political one, but rather a theoretical one, which needs, at this moment of constructing postcolonialism, this ideology and politics. A postcolonial approach is, precisely, the discovery of the speech of the Subaltern. It is a discovery that this speech is a process. Who, I want us to ask, is this informant-Subject I am studying? Is she the one I see, or think I see, before me, today, now? Is she as static as I am presuming her to be? Or is she the one I could glimpse as emerging, if I tried, a process I could also decipher, but would have to refine my approach further in order to catch successfully in my vision? Is she the one I think I hear, or is she the other tenor (too) that is trying to sound and is practising its cadences before suddenly sounding out loud and clear? Many people make a preparatory sound in their throats before they speak. Many express themselves through sounds that cannot be quite transliterated. Many sounds definitely exist around us but are near-inaudible until we are past a certain training. The theoretical point here is about the history within each of us, interacting with the history that has produced us. A person is not a being nor a becoming; and at any rate, not a fact, or the end of an enquiry; but a history negotiating with itself, or an ongoing enquiry. Scholars, of all people, know that they are learning and therefore in movement all the time. So, they must accept, is the informant part of a process, and looking for change. 
${ }^{\mathrm{i}}$ Ruth Behar (1996) suggests that there is a vulnerability of scholars to what they observe because of human, if not more specific social and historical connections. Her point, made particularly in the first chapter, seems to me valuable, but particularly true for the US population, made us of so many diasporic and global emotional and material movements.

ii There is an in-between situation, that of the diasporic scholar who goes to study the society she has "left behind” (for India: Chatterjee 2001, Narayan 1993, Visweswaran 1994). I do not fully share the discomfiture of these scholars as insiders-outsiders, partly because their situation does not seem to me generically different to that of scholars from either the same society or from one totally different (all are insiders-outsiders); and partly because the historian in me resents their positioning as a simplification of the class and educational histories of the societies concerned that has produced scores of intellectuals who live in several worlds just like these diasporic scholars but are not related to.

iii A word about servants is necessary. An Indian scholar in the field might have no desire to live in the field in the self-denying, mistakenly-authentic “Indian”, or simply American, ways adopted by scholars from the USA. As narrated bluntly in the fieldwork memoirs called Friends,

Brothers and Informants (1992), many of the Indian author's American colleagues denied themselves elementary comforts adopted by all Indians who can afford them: to deal with the weather in different seasons, eat and sleep in preferred ways, arrange spaces for their maximal comfort and treat India as a civilized country of creature comforts. Americans' tolerance for discomfort and even garbage, as something 'natural' to India, was astonishing to the author of these memoirs. One part of my own chosen lifestyle, as far as allowed by one's research grant of course, was to have the servants I deemed necessary, servants being an accepted necessity by those of us who know South Asia, like purified drinking water, and refrigerators and air coolers in summer. My choice of servants was based on chance and availability, and it was a (wonderful, sad) coincidence that they were from the same large class of people from whom came my informants.

iv At several places Marcus and Fischer (1986) speak of “us"/"our” and "them”/”other” (such as ix-x, 1) which is perhaps meant only to highlight the contribution of Anthropology in overcoming these distinctions, but surely these entities are not as bounded, discrete, and transparent as the language suggests? 